\title{
Accelerated ageing of paper: effect of lignin content and humidity on tensile properties
}

\author{
Edyta Małachowska ${ }^{1,2^{*}}$, Marcin Dubowik ${ }^{2}$, Piotr Boruszewski ${ }^{1}$ and Piotr Przybysz ${ }^{1,2}$
}

\begin{abstract}
Paper degradation menaces the useful lifetime of books, manuscripts, and works on paper during storage, circulation, and display in libraries, archives, and museums. Severe damages such as embrittlement, decay, and mold often occur to the paper that might threaten to lose cultural heritage. However, the shelf life of papers stored in suitable conditions can be extended by hundreds of years. The most important external factors affecting the deterioration of paperbased materials include, in particular, changes in temperature and air humidity. In this study, the effects of accelerated aging under different conditions, including substantially different relative humidity, were considered relative to the strength properties of the paper sheets. These include the mechanical strength, such as breaking length, tear resistance, and bursting strength of the paper samples before and after dry heat aging and hydrothermal aging. Samples with various content of lignin produced in neutral pH were examined to exclude the adverse influence of acidity on paper properties. The results indicate that impact of moisture on tensile properties and $\mathrm{pH}$-value of paper is much greater than the effect of increased temperature. The results of this work are intended to consolidate and expand the theoretical foundation and provide technical support for the conservators and library staff on the storage of paper cultural relics.
\end{abstract}

Keywords: Cellulose degradation, Tensile properties, Paper ageing, Paper durability, Accelerated ageing tests

\section{Introduction}

Paper is a material of hydrophilic nature, for this reason, it absorbs a significant amount of water vapour from the air, which is maintained in the product in the form of hygroscopic water. This, in turn, contributes to primarily initiate the destructive process of hydrolysis in the paper [1] but also many other paper-destroying processes. The adsorption of gaseous pollutants also increases with the moisture content of paper and their activity increases the destructive effect on paper [2-6]. As a result of fluctuations in the relative humidity of the air, impurities contained in the surrounding air accumulate in the paper. Periodic increases in relative humidity in the air also lead to the breakdown of hydrogen bonds in the paper.

\footnotetext{
*Correspondence: edyta_malachowska@sggw.edu.pl

${ }^{1}$ Institute of Wood Sciences and Furniture, Warsaw University of Life Sciences - SGGW, 159 Nowoursynowska Str, 02-787 Warsaw, Poland Full list of author information is available at the end of the article
}

This breakdown of $\mathrm{H}$ bonds in paper proceeds spontaneously, but under natural conditions it is an extremely slow process. The increase of moisture content in the paper causes significantly acceleration of the breakdown of $\mathrm{H}$ bonds [7], which leads to a loss of paper strength in a non-conditioned environment. For these reasons, archival warehouses strive to keep the relative air humidity as optimum (and possibly constant) [8]. Recommended climatic conditions for the long-term storage of archive and library materials are the temperature of $14-18{ }^{\circ} \mathrm{C}$ and the relative humidity of $30-50 \%$ (for parchment documents: the temperature of $2-18{ }^{\circ} \mathrm{C}$ and $50-60 \%$ humidity) [9]. Short-term fluctuations in relative humidity are dangerous for paper also from the microbiological point of view because such fluctuations create conditions for the rapid growth of bacteria and fungi $[10,11]$. The archives ensure that the fluctuation of this parameter do not exceed 10 $15 \%$ (depending on the season), because this level is safe for most archival materials. Changes in the water vapour
Springer Open

(c) The Author(s) 2021. Open Access This article is licensed under a Creative Commons Attribution 4.0 International License, which permits use, sharing, adaptation, distribution and reproduction in any medium or format, as long as you give appropriate credit to the original author(s) and the source, provide a link to the Creative Commons licence, and indicate if changes were made. The images or other third party material in this article are included in the article's Creative Commons licence, unless indicated otherwise in a credit line to the material. If material is not included in the article's Creative Commons licence and your intended use is not permitted by statutory regulation or exceeds the permitted use, you will need to obtain permission directly from the copyright holder. To view a copy of this licence, visit http://creativecommons.org/licenses/by/4.0/. The Creative Commons Public Domain Dedication waiver (http://creativeco mmons.org/publicdomain/zero/1.0/) applies to the data made available in this article, unless otherwise stated in a credit line to the data. 
content in the air, and consequently in the material, also cause a number of other destructive changes for paper (e.g., shrinkage, crumbling of paper, breaking glue joints, dissolving glues and other binders in books, causing, among others, the formation of streaks and migration of dyes and pigments, which then reflect on the adjacent pages) and other book constituents that can be found in archival collections (e.g., beeswax seals, acid decayed leather 'red rot') [12, 13].

Despite an overall statement about the strong influence of increase in paper moisture content on the intensity of its ageing, scientists have failed to establish the exact relationship between paper moisture and the rate constant of cellulose degradation reaction for a long time. Publications in which the aforementioned relationships for bleached pulp were related quantitatively appeared only at the turn of the 20th and 21st century [14, 15]. According to them, the rate of paper degradation in relation to air humidity at $90{ }^{\circ} \mathrm{C}$ is variable. In the initial stage, it increases sharply with the increase of air relative humidity to about $10-25 \%$. In the second stage, for humidity from 10 to $25 \%$ to $50-75 \%$, the increase in the constant degradation rate is slight. Over $50-75 \%$ humidity, on the other hand, a sudden increase in the degradation rate is again observed. The nature of the relationship does not change, even though in the obtained humidity ranges there are major discrepancies. However, other research shows an exponential dependence of the rate of degradation on relative humidity, at least at elevated temperatures [16]. Strang and Grattan [17] argue that it is the concentration of water in the cell wall rather than the concentration of water vapour in the atmosphere, which has a direct impact on the rate of degradation of paper, and it is worth stressing this. It should also be remembered that most of the literature discusses degradation at constant temperature and humidity. Meanwhile, there is much assumption on the effects of imbalances in temperature and relative humidity and opinions on the subject are contradictory [18-23].

The increase in temperature, as humidity, also has a destructive impact on paper. The degree of cellulose destruction (decrease in the DP and crystallinity degree) is all the superior, the higher the temperature and the longer time of its interaction with the paper [24]. Heating of cellulose materials in the air atmosphere up to 100 ${ }^{\circ} \mathrm{C}$ does not contribute to significant external or chemical changes of cellulose. However, prolonged exposure of paper to the elevated temperature may cause a depolymerization of cellulose. Increased temperature and the presence of water also accelerate disintegration of unstable peroxide bonds [25]. The speed of cellulose oxidation process in the paper, in turn, depends on the rate of decomposition of these bonds. Increased temperature also contributes to the formation of radicals which initiate the oxidation reaction [26]. The oxidation of functional groups in glucose units within the cellulose chain usually occurs in parallel with the disruption of the glycosidic bonds, which contributes to a decrease in the degree of polymerization. An increase in the proportion of the low molecular weight fraction and a decrease in the mean degree of polymerization as a result of degradation of the cellulose, hemicellulose and lignin macromolecules caused by ageing leads to deterioration of paper properties.

Researchers and conservators take advantage of the observed temperature and humidity dependence of the rates of paper destruction. Obviously, the superior purpose is to slow the rates of degradation in cultural heritage collections. Heating of paper materials in differential humidity conditions causes accelerated or artificial aging allowing the simulation of the natural ageing process of paper. This is a useful method, enabling one to estimate the impact of excessively warm and humid long-term storage conditions as a factor affecting lignocellulosic materials degradation [27]. However, the collection of knowledge and formation of the scientific basis for the accelerated aging of paper was gradual and took many decades. Two views have developed since then: according to the first, it was a reliable test method, according to the second - accelerated aging can never reproduce natural aging. For several decades, accelerated tests consisted in aging the paper samples at elevated temperatures, ignoring the role of water vapor in the course of acidic hydrolysis of paper. In recent decades, aging tests have already been carried out in a humid atmosphere, and methods have appeared that take into account the action of many other destructive factors (light radiation, gases, chemicals). There have also been projects to compare the natural and accelerated aging of paper, which found accelerated aging to be an excellent approximation of natural aging and to be an appropriate and reliable tool for predicting the life of the paper.

Despite the numerous studies of paper degradation, there is not much work where it has been established generally relationships taking into account the agents of deterioration ( $\mathrm{T}, \mathrm{RH})$, chemical composition and $\mathrm{pH}$-value of paper [28]. This fact has led authors to undertake studies in this direction. In this work, it was therefore studied the extent to which the humidity in the air affects the strength of papers with different chemical composition. Papers were produced at neutral $\mathrm{pH}$ to eliminate the impact of acidity on the rate of degradation processes, because widely acknowledged that the role of acidification in accelerated ageing of paper has been decisive. Artificially aged papers characterized differential lignin content, because a literature has shown there is no 
unified data available on the impact of lignin content on the ageing of paper produced in neutral environments. And furthermore, contemporary analysis calls into question the general conviction of negative impact of lignin on paper durability. The accelerated ageing conditions were adjusted to achieve maximum degradation effect and also to compare it with the conditions obtained in dry atmosphere.

\section{Materials and methods \\ Cellulosic pulps}

Pine wood (Pinus sylvestris L.) was used in this work. The pulps with a broad spectrum of lignin content were prepared from wood raw material in order to compare changes in tensile properties of papers with differential chemical compositions under various paper-ageing conditions. The chemical composition of pulps was established within the scope of earlier research [29].

Cellulosic pine pulps were prepared using the sulphate method described by Modrzejewski et al. [30]. The amount of active alkali added was $20-38 \%$ (to dry weight wood) and the liquid to wood ratio (v:w) was 4 . The dry weight (DW) of all materials was determined before pulping. The pulping processes were conducted in a $15 \mathrm{dm}^{3}$ PD-114 stainless laboratory digester (Danex, Katowice, Poland), with temperature regulation (water jacket) and agitation ( 3 swings $/ \mathrm{min}$, swinging angle of $60^{\circ}$ ) mechanisms. Wood was suspended in an alkaline sulphate solution and heated. The maximal digestion temperature was $172{ }^{\circ} \mathrm{C}$. The heating time was $120 \mathrm{~min}$, and cooking at the maximum temperature also took place for $120 \mathrm{~min}$. The temperature was then decreased to $25 \pm 5{ }^{\circ} \mathrm{C}$ using cold tap water. After delignification, the material was washed several times with demineralised water and incubated overnight in demineralised water to remove the residual alkali soluble fractions. The solids were disintegrated for $3 \mathrm{~min}$ in a laboratory JAC SHPD28D propeller pulp disintegrator (Danex, Katowice, Poland), and the fibres were screened using a PS-114 membrane screener (Danex, Katowice, Poland) equipped with a $0.2 \mathrm{~mm}$ gap screen. After screening, the pulps were dried at ambient temperature for $48 \mathrm{~h}$. The dry pulps were stored in hermetically sealed vials until being used in further experiments.

The residual lignin content expressed as the Kappa number (ISO 302:2015) of the pulps was determined. All chemical analyses were performed in triplicate for each pulp.

\section{Paper samples}

The pulps were used to prepare laboratory scale test sheets. Before processing, the pulps were soaked in water for $24 \mathrm{~h}$. They were treated in a laboratory scale JAC SHPD28D propeller pulp disintegrator (Danex, Katowice,
Poland), in accordance with PN EN ISO 5263-1 (2006), at 23,000 revolutions. Refining was performed in a JAC PFID12X PFI mill (Danex, Katowice, Poland) with a single batch comprising $22.5 \mathrm{~g}$ of dry pulp, in accordance with PN-EN ISO 5264-2 (2011). The cellulosic pulps were refined to $30^{\circ} \mathrm{SR}$, at which value they exhibited maximum strength properties and could be easily dehydrated. The Schopper-Riegler freeness was measured using a Schopper-Riegler apparatus (Danex, Katowice, Poland) in accordance with PN-EN ISO 5267-1 (2002). The next step was forming sheets of paper in a Rapid-Koethen class apparatus. This was performed in accordance with PN-EN ISO 5269-2 (2007). Each laboratory paper sheet was specified to have a base weight of $80 \mathrm{~g} / \mathrm{m}^{2}$. Only sheets with base weights in the range $79-81 \mathrm{~g} / \mathrm{m}^{2}$ were accepted for ageing tests. The manufactured sheets of paper were stored in air conditioned conditions until being used in further experiments, so they were not susceptible to degradation processes caused by environmental factors.

Lignin content in the obtained paper samples was in the range of 3-14\%, which corresponds to a kappa number in the scope of 19-90. In the context of this work the nomenclature of samples is based on the Kappa number determined for each pulp.

\section{Analysis of paper properties}

The test sheets were conditioned for $24 \mathrm{~h}$ at a temperature of $23 \pm 1{ }^{\circ} \mathrm{C}$ and a relative humidity of $50 \pm 2 \%$ (ISO 187:1990) before determination of their mechanical properties (before and after accelerated aging tests), namely, their breaking length (PN-EN ISO 1924-2:2010), tear resistance (PN-EN ISO 1974:2012), and bursting strength (PN-EN ISO 2758:2005). The tensile properties were performed for aged and non-aged samples after 90 days of ageing tests; at least 12 measurements were recorded; the calculated standard error is shown in the bars in Figs. 2, 3 and 4.

The $\mathrm{pH}$ was tested using the Flatrode electrode made by Hamilton [31]. Calibration and measurements were carried out based on the electrode user manual available on the producer website [32]. The 809 TitrandoMetrohm system was used for the calibration and $\mathrm{pH}$ measurements.

\section{Ageing tests}

The samples of obtained papers with different delignification degrees were artificially aged under two ageing conditions. One test was conducted at $90{ }^{\circ} \mathrm{C}$ and dry atmosphere using a BMT Venticell laboratory dryer ("DRY" method). Parallel set of samples was also aged according to ASTM standard [33] at elevated temperature and presence of water vapour $\left(90{ }^{\circ} \mathrm{C}\right.$ and $59 \%$ 
relative humidity, denoted as "WET" method) in a climatic chamber (Memmert HCP246). The time of sample ageing was 0-90 days for both WET and DRY methods.

\section{Results}

Impact of accelerated ageing conditions on the paper $\mathrm{pH}$

Based on the analysis of performed research on accelerated ageing of papers with different lignin content, under the influence of heating at increased temperature and humidity, it was found that with an increase of ageing time the $\mathrm{pH}$-value of a paper decreases. After 90 days, the reduction in the $\mathrm{pH}$ index is much more pronounced for papers aged with the WET90 method $\left(90{ }^{\circ} \mathrm{C}, 59 \%\right.$ $\mathrm{RH}$ ), $\mathrm{pH}$ of samples decreased from 7 to about 5 (Fig. 1b). In the case of the DRY 90 method $\left(90{ }^{\circ} \mathrm{C}, 0 \% \mathrm{RH}\right)$, the $\mathrm{pH}$ value of the examined papers fell from 7 to about 6 (Fig. 1a). The final pH of the samples for both methods of ageing is similar with an average of 5.8 for papers aged in zero relative humidity conditions and 5.4 for the WET90 method. Aged papers have thus slightly acid $\mathrm{pH}$ at the end of the accelerated ageing tests.

The dynamics of the $\mathrm{pH}$ value reduction is slightly different only in the initial period of ageing (until 24 days) depending on the method used. A greater downward trend at this time is observed for papers aged in conditions of increased humidity (Fig. 1b). After 24 days of testing, in most cases, the decline in the $\mathrm{pH}$-value remains at a slight, uniform level. Interestingly, the lignin content in the pulp had inconsiderable impact on the amount of pH decrease (under DRY90 and WET90 method conditions).

\section{Impact of accelerated ageing conditions on the breaking length of paper}

The breaking length of the examined papers decreased by $500 \mathrm{~m}$ (after 90 days of testing) under the DRY90 method conditions, while the decrease in the index of samples with different lignin content varied from 3.7 to $8.0 \%$ (Fig. 2). Much bigger changes took place during the tests in conditions of increased relative humidity. Under the conditions specified in this method, the parameter decreased by approximately $3600 \mathrm{~m}$ in relation to the initial values and reduction of the index was included in the range of $37.2-40.8 \%$ depending on the amount of lignin in the sample (Fig. 2) [29]. Therefore, the decrease in breaking length under higher humidity conditions was 7 times higher, which could be explained by the role of water in the cellulose depolymerisation process. Noteworthy is also the fact that the lignin content in pulp has no significant impact on the destruction level, and the initial value of breaking length depended on the degree of pulp delignification. This is due to the fact that the degree of pulp delignification determines the pulp chemical properties and the fiber dimensions. The papers made of pulps with a kappa number of $47-64$ are characterized by the maximum degree of cellulose crystallinity and the maximum average fiber length therefore they have achieved maximum strength properties.

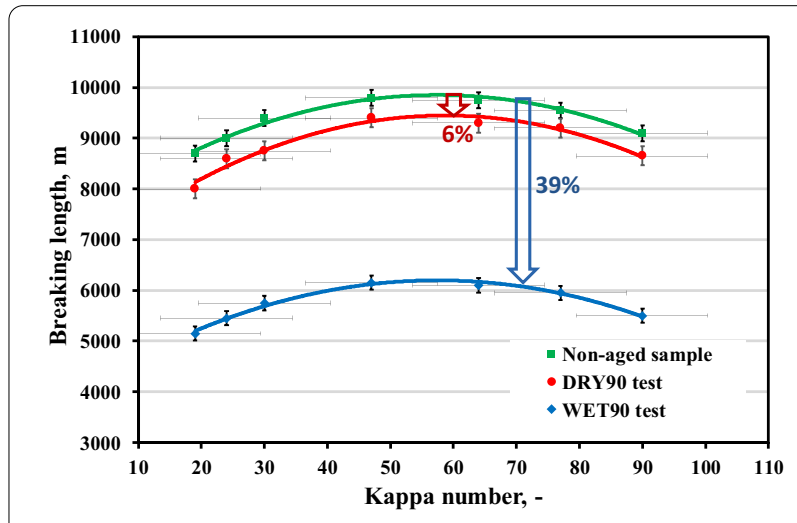

Fig. 2 Effect of paper-ageing conditions on changes in the breaking length of papers with different lignin contents
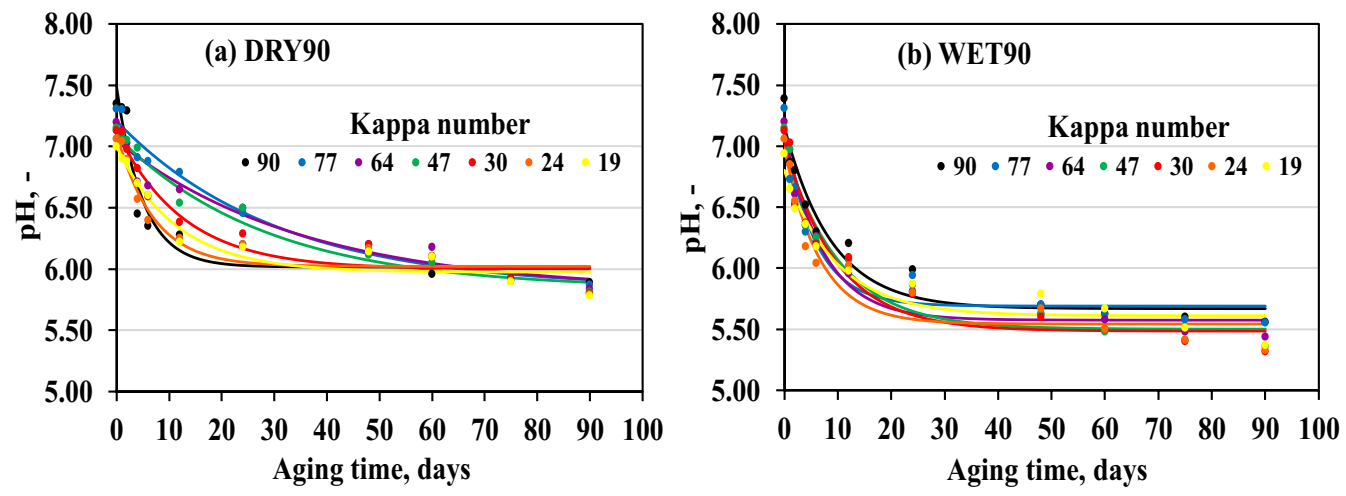

Fig. 1 Effect of paper-ageing conditions on pH changes of papers with different lignin contents: a dry atmosphere; $\mathbf{b}$ humid atmosphere 


\section{Impact of accelerated ageing conditions on the tear resistance of paper}

Figure 3 presents the difference in the reduction of the tear resistance from base-line depending on the ageing test applicable, and also the influence of pulp delignification on the level of the index decreases. The largest decline of tear resistance was recorded for pulp with 89.7 Kappa number (after 90 days of testing). The initial value of parameter for this sample was $424 \mathrm{mN}$, while at the end of the ageing tests its value is down to $125 \mathrm{mN}$ (WET90 method) and $342 \mathrm{mN}$ (DRY90 method), corresponding to a decrease by $70.5 \%$ and $19.3 \%$, respectively. The other papers lost $62.1-66.6 \%$ of their initial properties in the case of the WET90 method and 17.2-18.9\% in zero relative humidity conditions. In the case of the WET90 test, the tear resistance was lower by about 300 $\mathrm{mN}$ from the starting value, so the decrease in tear resistance as a result of ageing under conditions of increased relative humidity was 3.5 times higher compared to the DRY90 method.

Furthermore, it was found that the lignin content in pulp has no significant impact on the tear resistance drop under the testing conditions used. The lignin content, however, has a considerable impact on the initial value of the parameter, this is due to the fact, that the degree of polymerization falls during the delignification process, which consequent decrease in initial value of this parameter.

\section{Impact of accelerated ageing conditions on the bursting strength of paper}

The next examined parameter was the bursting strength. The decrease in the index for the examined papers varied from 20.3 to $25.2 \%$, corresponding to a parameter decrease of around $120 \mathrm{kPa}$ as a result of ageing with the DRY90 method. The indicator value under conditions of increased humidity decreased by an average of $366 \mathrm{kPa}$ in relation to the initial value, while the percentage decrease was at the level of $61.7-74.0 \%$ after 90 days of test [29]. So, the decrease in bursting strength under the WET90 method was 3 times higher (Fig. 4).

The results obtained prove that the amount of lignin content in the pulp does not affect the nature of the course and size of the index changes over time at the used tests conditions, although it defines the initial values of bursting strength, similarly to the breaking length and tear resistance.

\section{Discussion}

Mechanical strength is one of the basic features of ancient and utility papers, and therefore this is of interest to both papermakers and conservators. Moreover,

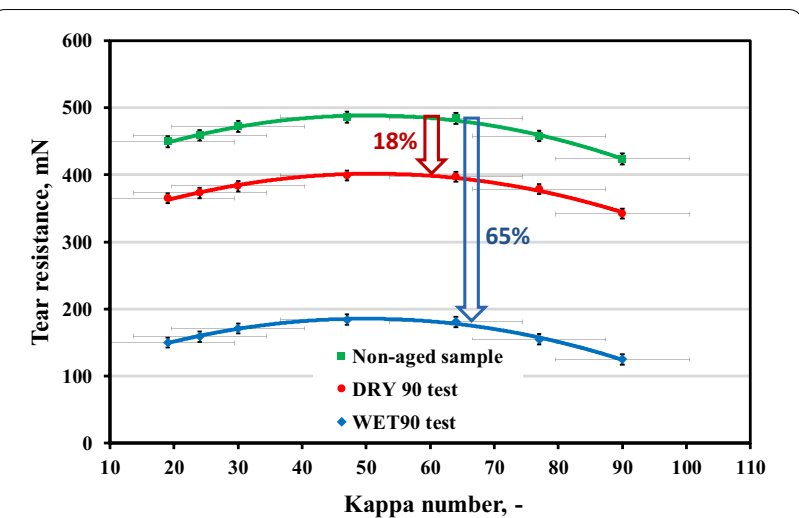

Fig. 3 Effect of paper-ageing conditions on changes in the tear resistance of papers with different lignin contents

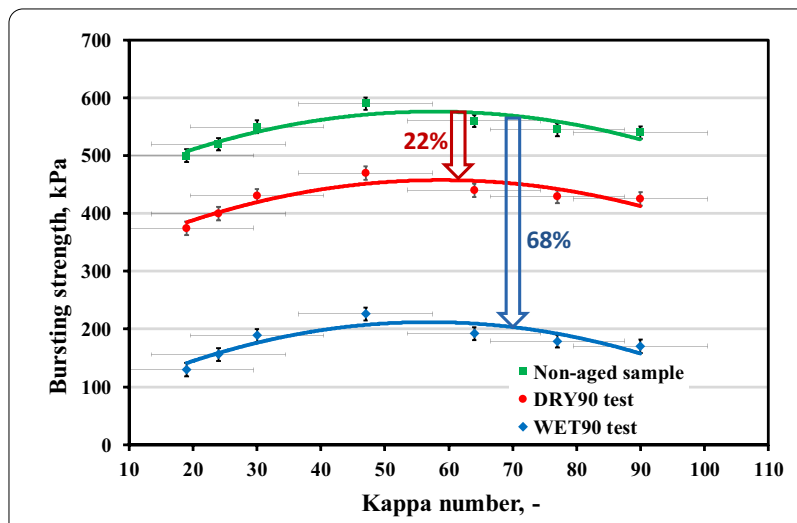

Fig. 4 Effect of paper-ageing conditions on changes in the bursting strength of papers with different lignin contents

the change in mechanical resistance is one of the first visible effects of paper ageing. Impact of the key parameters causing accelerated degradation of paper (RH, T) on changes in its strength properties was therefore analyzed in this work. Although this topic has been discussed repeatedly by many researchers, this work significantly contributes to the field of paper ageing science, because the tested papers were formed in an inert environment, i.e. without the addition of aluminum sulphate. In literature there is little information about the studies like that, although increased durability of neutral or alkaline papers have long been acknowledged [3, 34, 35]. Previous studies focused mainly on estimating the influence of the paper acidic $\mathrm{pH}$ on its mechanical [36-38] and optical properties [39-41].

The mechanical tests have been chosen to illustrate changes of the most important strength properties of paper, i.e. breaking length, tear resistance, and bursting strength. Conducted ageing tests of samples under the DRY90 and WET90 method conditions clearly indicate 
that water has been shown to have a strong influence on cellulose ageing (Figs. 2, 3 and 4) due to its role in degradation chemistry, particularly with respect to hydrolysis. These results are in line with observations made by other researchers [15, 42-44]. However, obtained results are difficult to quantitatively compare with the effects of other researchers because they relate to acid papers [45] or previously subjected to a deacidification process [46]. The chemical composition of the tested samples is also often unknown. Neglecting impact of lignin in previous research hampers understanding the materials strength behavior during aging. The conditions for the accelerated ageing process also often vary. But it is also worth noting that water has long been acknowledged to play an essential role in paper strength because of its ability to disrupt intermolecular hydrogen bonding $[47,48]$, which leads to a decrease in the elastic modulus of paper [49], and these changes are irreversible [50].

It was also argued that the lignin content in the pulp produced in a neutral environment does not affect the reduction level of the above-mentioned parameters under the conditions of the accelerated ageing tests applied. This is a pioneering result in the field of ageing paper research, which is supported by studies using mechanical tests and detailed instrumental methods which were presented in our previous published research [29].

The test papers have been produced in an inert environment. The glycosidic bonds of cellulose ensure its stability only in an alkaline and neutral environment. However, on the basis of the analysis performed, it can be noticed that the $\mathrm{pH}$ of the papers decreased to the value of $5.4-5.8$ as a result of the increased temperature and humidity (Fig. 1). Previous research and experience have proven that the rate of acid hydrolysis depends on the initial $\mathrm{pH}$ value [51]. Moisture in paper not only represents a reactant, but also the reaction medium for hydrolysis and is also an additional source of radicals (e.g. hydronium ions) [52]. The increase in the concentration of hydronium ions in the acidic environment accelerates the process of hydrolytic breakdown of glycosidic bonds. The scission of intramolecular bonds leads to a decrease in average molecular weight of cellulose, which represents the number of monomers in a cellulose polymer (i.e. DP - degree of polymerisation), thereby reducing the strength paper properties $[53,54]$. This phenomenon is clearly documented in several papers [55-59]. The influence of $\mathrm{pH}$ on the strength properties of paper has been analyzed by many researchers [37, 38, 60]. Despite the general agreement in the test results regarding the destructive effect of moisture on the paper $\mathrm{pH}$, and thus its strength properties, these results cannot be directly compared because researchers did not take into account the lignin content in the tested sample or papers of pure cellulose were tested [44]. It should be noted that the papers containing lignin, hemicellulose and other additives may have different ageing behaviour.

But in spite of the well-established fact that degradation is generally slower in dry environments [26], in accordance with our obtained results, it should be stressed that water forms intermolecular $\mathrm{H}$-bonds with cellulose and works as a plasticizer, which increases paper flexibility [20, 22]. Therefore, paper loses flexibility under low humidity conditions which can lead to physical damage during handling, as brittleness is increased [61]. However, too high moisture content of paper also leads to decreased elasticity. It was found that paper strength decreases by $5-10 \%$ for each unit percentage increase in the moisture content in paper [62].

Although microbiological degradation was beyond the scope of this work, it is also worth noting that most cellulolytic fungi thrive best in a slightly acidic environment. The optimal $\mathrm{pH}$ index for the growth of most types of fungi is in the range of 4.5-6.5 [63]. Therefore, papers stored in inappropriate conditions will be exposed to accelerated microbiological degradation [64] that contribute to weaken their mechanical resistance.

\section{Conclusions}

This study compared the effects of two accelerated aging tests, involving extremely different levels of relative humidity, on the deterioration of strength properties of paper sheets prepared from pine pulp with different kappa numbers. The obtained results indicate that the increased relative humidity contributes to $40-68 \%$ reduction of the paper strength properties due to the role of water in degradation chemistry, particularly with respect to hydrolysis. In the meantime, the ageing of the paper samples under the same process conditions, but without water, causes a decrease in strength properties by $5-22 \%$. It is significant to note that the lignin content in the pulp has no significant impact on the level of decline in strength properties of paper produced under neutral $\mathrm{pH}$. But importantly, the influence of environmental parameters ( $\mathrm{T}, \mathrm{RH}$, and so on) on paper durability can be objectively assessed after only taking into account both the chemical composition of the paper and its $\mathrm{pH}$ value, which is often overlooked in other research. And it should finally be noted that used destructive techniques are still valid, because no simply and quick options have emerged to fully replace classical mechanical tests. The instrumental methods are usually very expensive and are not available in all laboratories. However, it is worth adding that despite the fact that destructive techniques are undoubtedly valid for sacrificial samples, however, 
sampling of heritage materials is being more and more rarely permitted.

The information presented in this article can thus be helpful to increase understanding of degradation mechanisms. This knowledge may be useful for both paper technologists and conservators in terms of both research and strategies that can be used to decrease the rate of degradation of books, manuscripts, maps, and other works on paper in libraries, museums, and archives.

\section{Acknowledgements}

Not applicable.

\section{Authors' contributions}

Conceptualization, EM and PP; methodology, EM and MD; literature review, MD; writing-original draft preparation, EM; writing-review and editing, EM and PB; funds acquisition for research, PP. All authors read and approved the final manuscript.

\section{Funding}

This research was funded by National Center of Research and Development in Poland, Grant Numbers POIR.01.01.01-00-0084/17 and POIR.04.01.04-00-0022/18

\section{Availability of data and materials}

The datasets used and/or analysed during the current study are available from the corresponding author on reasonable request.

\section{Declarations}

\section{Competing interests}

The authors declare that they have no competing interests.

\section{Author details}

${ }^{1}$ Institute of Wood Sciences and Furniture, Warsaw University of Life Sciences - SGGW, 159 Nowoursynowska Str, 02-787 Warsaw, Poland. ${ }^{2}$ Natural Fibers Advanced Technologies, 42A Blekitna Str, 93-322 Lodz, Poland.

Received: 7 October 2021 Accepted: 8 October 2021

Published online: 16 October 2021

\section{References}

1. Lipinsky E. Perspectives on preparation of cellulose for hydrolysis. In: Brown RD, Jurasek L, editors. Hydrolysis of cellulose: mechanisms of enzymatic and acid catalysis. Advances in chemistry. Advances in Chemistry. Washington, DC: American Chemical Society; 1979.

2. Strzelczyk B. Problems of mass acidification of documents in warehouses. In: Nałęcz D, editor. Archives to the Challenges of the 21st Century. Toruń: Diary of the 3rd Common Congress of Polish Archivists; 1997. p. 292-293.

3. Arney JS, Jacobs AJ. Accelerated aging of paper: the relative importance of atmospheric oxidation. Tappi J. 1979;62:89-91.

4. Garminski EL, Parks EJ, Toth EE. The effect of temperature and moisture on the accelerated aging of paper. Durab Macromol Mater. 1979. https://doi. org/10.1021/bk-1979-0095.ch024.

5. Vitale T, Erhardt D. Changes in Paper Color due to Artifical Aging and the Effects of Washing on Color Removal. In: Bridgland, J, editor. Preprints for the ICOM Committee for Conservation, 10th Triennial Meeting. Volume 2. Washington, DC: 22-27 August 1993. p. 507-515.

6. Mendenhall GD, Kelly GB, Williams JC. The application of several empirical equations to describe the change of properties of paper on accelerated aging. In: Williams JC, editor. Preservation of Paper and Textiles of Historic and Artistic Interest II. Advances in Chemistry Series 193. Washington, DC American Chemical Society; 1981. pp. 177-88.
7. Hirn U, Schennach R. Comprehensive analysis of individual pulp fiber bonds quantifies the mechanisms of fiber bonding in paper. Sci Rep. 2015;5:10503. https://doi.org/10.1038/srep10503.

8. Wojciechowski P. Protection and Conservation of Resource in the State Archives in Poland. PhD Dissertation. Institute of History of the Adam Mickiewicz University; 2014

9. ISO 11799:2015. Information and documentation — Document storage requirements for archive and library materials.

10. Kowalik R, Sadurska I. Research on the protection of archives against the harmful effects of microorganisms. Archeion. 1982;73:157-93.

11. Flannigan B. Microbial Aerosols in Buildings: Origins, Health Implications and Controls. Lodz: 2nd International Conference Microbial Biodegradation and Biodeterioration of Technical Materials; 2001. p. 11-27.

12. Strzelczyk AB. Microbiological destruction of library collections. The causes and symptoms of destruction. Scientific Papers of the University of Silesia. Book Stud. 1997;10:81-92.

13. Valentín N, García R, De Luis O, Maekwa S. Microbial control in archives, libraries and museums by ventilation systems. Restaurator. 1998;19:85-107.

14. Zou X, Uesaka T, Gurnagul N. Prediction of paper permanence by accelerated aging I. Kinetic analysis of the aging process. Cellulose. 1996;3:24367. https://doi.org/10.1007/BF02228805.

15. Barański A, Dutka D, Dziembaj R, Konieczna-Molenda A, Łagan JM. Effect of relative humidity on the degradation rate of cellulose. Methodology studies. Restaurator. 2004;25:68-74. https://doi.org/10.1515/REST.2004.68.

16. Kočar D, Strlič M, Kolar J, Rychlý J, Pihlar B. Chemiluminescence from paper III: The effect of superoxide anion and water. Polym Degrad Stab. 2005;88:407-14. https://doi.org/10.1016/j.polymdegradstab.2004.12.005.

17. Strang T, Grattan D. Temperature and humidity considerations for the preservation of organic collections - the isoperm revisited. e-PS. 2009:6:122-8.

18. Shahani CJ, Hengemihle FH, Weberg N. The effect of variations in relative humidity on the accelerated aging of paper. In: Historic Textile and Paper Materials II. Washington, DC: American Chemical Society; 1989. pp. 63-80.

19. Bandyopadhyay A, Ramarao BV, Ramaswamy S. Transient moisture diffusion through paperboard materials. Colloids Surf A: Physicochem Eng Asp. 2002;206:455-67. https://doi.org/10.1016/S0927-7757(02)00067-5.

20. Vittadini E, Dickinson LC, Chinachoti P. $1 \mathrm{H}$ and $2 \mathrm{H}$ NMR mobility in cellulose. Carbohydr Polym. 2001;46:46-57.

21. Bigourdan JL, Reilly JM. Effects of Fluctuating Environments on Paper Materials - Stability and Practical Significance for Preservation. Paris: La Conservation à l'ère du numérique: actes des quatrièmes journées internationales d'études de l'ARSAG; 27-30 May 2002. p. 180-192.

22. Sandy M, Manning A, Bollet F. Changes in the tensile properties of paper in response to fluctuating relative humidity - Relevance to paper conservation. International Circular of Graphic Education and Research; 2009. pp. 6-14.

23. Sandy M, Manning A, Bollet F. Changes in crystallinity of cellulose in response to changes in relative humidity and acid treatment. Restaurator. 2010;31:1-18.

24. Sánchez-Jiménez PE, Pérez-Maqueda LA, Perejón A, Pascual-Cosp J, Benítez-Guerrero M, Criado JM. An improved model for the kinetic description of the thermal degradation of cellulose. Cellulose. 2011;18:1487-98. https://doi.org/10.1007/s10570-011-9602-3.

25. Strlic M, Kolar J, Kočar D, Rychlý J. Theromo-oxidative degradation. In: Strlič M, Kolar J, editors. Aging and stabilization of paper. Ljubljana: National and University Library; 2004. pp. 101-20.

26. Malešič J, Kolar J, Strlič M, Kočar D, Fromageot D, Lemaire J, Haillant O. Photo-induced degradation of cellulose. Polym Degrad Stab. 2005;89:649. https://doi.org/10.1016/j.polymdegradstab.2005.01.003.

27. Porck HJ. Rate of paper degradation - the predictive value of artificial aging tests. European Amsterdam: Commission on Preservation and Access; 2000.

28. Strlič M, Grossi CM, Dillon C, Bell N, Fouseki K, Brimblecombe P, Menart E, Ntanos K, Lindsay W, Thickett D, France F, Bruin G. Damage function for historic paper. Part III: Isochrones and demography of collections. Herit Sci. 2015;3:40. https://doi.org/10.1186/s40494-015-0069-7.

29. Małachowska E, Dubowik M, Boruszewski P, Łojewska J, Przybysz P. Influence of lignin content in cellulose pulp on paper durability. Sci Rep. 2020;10:19998. https://doi.org/10.1038/s41598-020-77101-2. 
30. Modrzejewski K, Olszewski J, Rutkowski J. Analysis in papermaking industry. Lodz: Editorial Office of the Lodz University of Technology; 1969. p. $56-70,158$

31. Laboratory Electrodes. Hamilton. christianberner.no/\$-1/file/flatrode-frahamilton.pdf. Accessed 2 Dec 2020.

32. Flatrode. Hamilton. https://www.hamiltoncompany.com/products/labor atory-products/laboratory-sensors/ph/special-use/flatrode. Accessed 3 Dec 2020.

33. ASTM International. ASTM D6819. Standard test method for accelerated temperature ageing of printing and writing paper by dry oven exposure apparatus. 2007. https://doi.org/10.1520/D6819-02R07.

34. The deterioration and preservation. of paper: some essential facts. Library of congress. https://www.loc.gov/preservation/care/deterioratebrochure. html. Accessed 18 Jan 2021.

35. Roberson DD. The evaluation of paper permanence and durability. Tappi. 1976:59:63-9.

36. Rudi H, Hamzeh Y, Ebrahimi G, Behrooz R, Nazhad MM. Influence of pH and conductivity on properties of paper made of polyelectrolyte multilayered recycled fibers. Ind Eng Chem Res. 2012;51:11054-8. https://doi org/10.1021/ie301467f.

37. Poggi G, Giorgi R, Toccafondi N, Katzur V, Baglioni P. Hydroxide nanoparticles for deacidification and concomitant inhibition of iron-gall ink corrosion of paper. Langmuir. 2010;26:19084-90. https://doi.org/10.1021/ la1030944.

38. Jansson J. The influence of $\mathrm{pH}$ on fiber and paper properties. Master Thesis. Karlstad: Karlstad University; 2015.

39. Poirier NA, Pikulik I, Labadie M, Pageau A. The effect of $\mathrm{pH}$ on the optical properties of paper. J Pulp Pap Sci. 1996;22:419-23.

40. Varhimo P, Konn J, Lillandt M, Paltakari J. Brightness reduction of mechanical pulp in the wet end of a paper machine: the effect of $\mathrm{pH}$, pulp washing and shear rate. Nord Pulp Pap Res J. 2013;28:51-8. https:// doi.org/10.3183/npprj-2013-28-01-p051-058.

41. Jablonsky M, Vrska M, Katuscak S, Gemzicka E. Effect of pH and temperature on the optical properties in ozonization oxygen delignified hardwood kraft pulp. Bratislava: Challenges of Pulp and Papermaking Technology International Conference; 8-10 November 2006.

42. Mosier NS, Ladisch CM, Ladisch MR. Characterization of acid catalytic domains for cellulose hydrolysis and glucose degradation. Biotechnol Bioeng. 2002;79:610-8. https://doi.org/10.1002/bit.10316.

43. Havlínová B, Katuščáka S, Petrovičová M, Maková A, Brezová V. A study of mechanical properties of papers exposed to various methods of accelerated ageing. Part I. The effect of heat and humidity on original wood-pulp papers. J Cult Herit. 2009;10:222-31.

44. Zou X, Gurnagul N, Uesaka T, Bouchard J. Accelerated aging of papers of pure cellulose: mechanism of cellulose degradation and paper embrittlement. Polym Degrad Stab. 1994;43:393-402. https://doi.org/10.1016/ 0141-3910(94)90011-6.

45. Gonera H, Dąbrowski J. An adaptation of analysis methods used for reaction kinetics in solids to verifying and modifying a model for the paper ageing process. Przeglad Pap. 2019;75:761-6.

46. Cizova K, Jablonsky M, Briskarova A, Vizarova K, Kacik F, Sima J. Kinetic study of artefact paper degradation. Assessment of deacidification effects by folding endurance. Cell Chem Technol. 2018;52:99-104.

47. Hatakeyama T, Ikeda Y, Hatakeyama H. Structural change in the amorphous region of cellulose in the absence of water. In: Kennedy JF, editor. Wood and cellulosics. Chichester: Ellis Horwood: 1987. p. 23-30.
48. Caulfield DF, Steffes RA. Water-induced recrystallization of cellulose. Tappi. 1969;52:1361-6.

49. Batten GL, Nissan AH. Unified theory of the mechanical properties of paper and others H-bond-dominated solids. Tappi J. 1987;70:119-23.

50. Sharples A. In: Bikales NM, Segal L, editors. Cellulose and cellulose derivatives. Part V. New York: Wiley-Interscience; 1971. p. 995.

51. Calvini P, Gorassini A, Merlani AL. Autocatalytic degradation of cellulose paper in sealed vessels. Restaurator. 2007;28:47-54. https://doi.org/10. 1515/REST.2007.47.

52. Łojewski T, Zięba K, Knapik A, Bagniuk J, Lubańska A, Łojewska J. Evaluating paper degradation progress. Cross-linking between chromatographic, spectroscopic and chemical results. Appl Phys A. 2010;100:809-21. https://doi.org/10.1007/s00339-010-5657-5.

53. Bicchieri M, Brusa P. The bleaching of paper with the tert-butylamine complex. Restaurator. 1997;18:1-11. https://doi.org/10.1515/rest.1997. 18.1.1.

54. Jagiellonian Library. Paper Clinic. http://www.bj.uj.edu.pl/klinika-papieru/ papier. Accessed 14 Jan 2021

55. Jablonsky J, Kazikova S, Botkova M, Holubkova S. Kinetic dependences for the decrease of polymerization of paper undergoing accelerated ageing. Cell Chem Technol. 2013;46:625-30.

56. Berggren R, Molin U, Berthold F, Lennholm H, Lindstrom M. Alkaline degradation of birch and spruce: Influence of degradation conditions on molecular mass distributions and fibre strength. Carbohydr Polym. 2003:51:255-64. https://doi.org/10.1016/S0144-8617(02)00160-1.

57. Irklei VM, Kleiner YY, Vavrinyuk OS, Galbraikh LS. Kinetics of degradation of cellulose in basic medium. Fibre Chem. 2005:37:452-8.

58. Ding $H Z$, Wang ZD. On the degradation evolution equations of cellulose. Cellulose. 2008;15:205-24. https://doi.org/10.1007/s10570-007-9166-4.

59. Calvini P. On the meaning of the Emsley, Ding \& Wang and Calvini equations applied to the degradation of cellulose. Cellulose. 2014;21:1127-34. https://doi.org/10.1007/s10570-014-0224-4.

60. Stephens $\mathrm{CH}$, Barrett T, Whitmore PM, Wade JA, Mazurek J, Schilling M. Composition and condition of naturally aged papers. J Am Inst Conserv. 2008;47:201-15. https://doi.org/10.1179/019713608804539583.

61. Diniz JMBF, Gil MH, Castro JAAM. Hornification - its origin and interpretation in wood pulps. Wood Sci Technol. 2004;37:489-94. https://doi.org/ 10.1007/s00226-003-0216-2.

62. Bandyopadhyay A, Radhakrishnan H, Ramarao BV, Chatterjee SG. Moisture sorption response of paper subjected to ramp humidity changes: modeling and experiments. Ind Eng Chem Res. 2000;39:219-26. https:// doi.org/10.1021/ie990279w.

63. Potrzebnicka E. Characteristics of typical threats and damages in the library collections of the 19th and 20th century. In: Łojewski T, Pietrzyk Z, editors. Acidic paper. Threats to library and archives collections. Cracow: Jagiellonian Library; 2001. pp. 107-22.

64. Zotti M, Ferroni A, Calvini P. Microfungal biodetrioration of historic papers: preliminary FTIR and microbiological analyses. Int Biodeterior Biodegradation. 2008;62:186-94. https://doi.org/10.1016/j.ibiod.2008.01.005.

\section{Publisher's Note}

Springer Nature remains neutral with regard to jurisdictional claims in published maps and institutional affiliations. 